\title{
Potential role of scallops Argopecten irradians in deposition of particulate nutrient and trace elements in a eutrophic estuary, northern China
}

\author{
Feng Wang ${ }^{1,2,3}$, Yi Zhou ${ }^{1,2, *}$, Pengmei Wang ${ }^{1,3}$, Shaochun $\mathrm{Xu}^{1,3}$, Peng Liu ${ }^{1,3}$ \\ ${ }^{1}$ CAS Key Laboratory of Marine Ecology and Environmental Sciences, Institute of Oceanology, \\ Chinese Academy of Sciences, Qingdao 266071, PR China \\ ${ }^{2}$ Laboratory for Marine Ecology and Environmental Science, \\ Qingdao National Laboratory for Marine Science and Technology, Qingdao 266071, PR China \\ ${ }^{3}$ University of Chinese Academy of Sciences, Beijing 100049, PR China
}

\begin{abstract}
Anthropogenic inputs of nutrients and trace elements have globally significant impacts on coastal waters. In order to evaluate the effect of the filter-feeding bay scallop Argopecten irradians on benthic-pelagic coupling in a eutrophic estuary (Laizhou Bay), biodeposition of total suspended materials, particulate nutrient $(\mathrm{C}, \mathrm{N}, \mathrm{P})$ and trace elements $(\mathrm{Cu}, \mathrm{Zn}, \mathrm{Pb}$, $\mathrm{Cr}, \mathrm{Cd}, \mathrm{Hg}, \mathrm{As}$ ) were determined using modified sediment traps during autumn 2013. Results showed that biodeposition rates of the bay scallops were rather high compared with those reported for other bivalves. The allometric relationship between the biodeposition rate (BDR; $\mathrm{g}$ ind.$\left.^{-1} \mathrm{~d}^{-1}\right)$ and soft tissue dry weight $\left(W_{i} g\right.$ ind. $\left.{ }^{-1}\right)$ was modeled $\left(\mathrm{BDR}=a W^{b}\right)$ with the value of $a$ being 1.24 in September and dropping to 0.96 in October. The biodeposition contributed to the enrichment of organic matter, $\mathrm{C}$ and $\mathrm{N}$ in the local sediment. Trace element concentrations in the scallop biodeposits were significantly higher than those of the natural surrounding sediments, especially during the months of October and November. A. irradians significantly increases the mass fluxes from the water column to the bottom, with estimated 1140 tonnes of total suspended material being deposited to the seabed each day in the culture zone. Results also suggest that biotransformation and biodeposition by such efficient filter-feeders may play a pivotal role in the fate and transportation of particulate nutrient and trace elements in aquatic ecosystems. In coastal waters and estuaries subject to anthropogenic inputs, suspended bivalve aquaculture could be environmentally advantageous via intense filtering and biodeposition, potentially mitigating eutrophication and trace element pressures.
\end{abstract}

KEY WORDS: Biodeposition - Biogenic elements - Trace elements · Benthic-pelagic coupling · Bioremediation $\cdot$ Argopecten irradians $\cdot$ Filter-feeding bivalve $\cdot$ Laizhou Bay

\section{INTRODUCTION}

Oceans, especially their coastal waters and estuaries, have been strongly affected by numerous human activities (Halpern et al. 2008), and these impacts are projected to increase over the next few decades (Doney 2010). Anthropogenic nutrient inputs and resulting eutrophication is considered as one of the

*Corresponding author: yizhou@qdio.ac.cn major human perturbations to marine ecosystems worldwide (Smith et al. 1999). Eutrophication of coastal waters and estuaries has been a global problem for many years, and is considered one of the largest threats to coastal ecosystems (Micheli 1999, Wang et al. 2016, Andersen et al. 2017). Significant changes in nutrient regimes, including rising nutrient levels and alterations in nutrient supply, have led

(C) The authors 2018. Open Access under Creative Commons by Attribution Licence. Use, distribution and reproduction are unrestricted. Authors and original publication must be credited. 
to increased incidences of toxic algal blooms in marine waters worldwide (e.g. Anderson et al. 2008), posing great threats to many ecologically important ecosystems including salt marshes, seagrass meadows and coral reefs (Waycott et al. 2009, Deegan et al. 2012). In addition, elevated oceanic levels of trace elements have also raised a concern for the overall health of marine ecosystems, and indisputably, human health also (Doney 2010, Pan \& Wang 2012, Gao et al. 2014).

In shallow coastal waters, benthic filter-feeders (e.g. bivalves) often dominate the benthos, both in abundance and biomass. Previous studies have revealed that dense assemblages of filter-feeding bivalves in shallow waters can play a significant role in the pelagic-benthic coupling of organic matter, as well as controlling nutrient recycling (Haven \& Morales-Alamo 1972, Kautsky \& Evans 1987, Newell 2004, Zhou et al. 2006a, Beseres Pollack et al. 2013, Hoellein et al. 2015, Testa et al. 2015, Li et al. 2016). Densely cultured bivalves can filter large amounts of phytoplankton and other suspended particulate matter from the water column and enhance natural sedimentation (Newell 2004, Zhou et al. 2006a, Yuan et al. 2010, Zúniga et al. 2014). Through filtration and deposition of suspended particulate matter, intensive bivalve populations can exert a top-down control on phytoplankton biomass, resulting in alterations to the benthic environment and benthos composition (Grant et al. 1995, Crawford et al. 2003, Callier et al. 2007). The type and extent of changes in the benthic environment is linked to the scale and density of cultivation and hydrographic conditions of the mariculture waters. Generally, a combination of good water exchange and a diverse benthic community contribute to efficient dispersal and breakdown of the sedimented material, thus mitigating any negative impacts caused by shading, erosion and/or organic enrichment (Hayakawa et al. 2001). With a worldwide concern for the increase in waters impacted by eutrophication and trace element contamination, some researchers have suggested that the dramatic growth in bivalve mariculture could mitigate, or even biologically control the pollution of coastal waters (e.g. Zhou et al. 2006a, Stadmark \& Conley 2011, Petersen et al. 2014, Nielsen et al. 2016, Grizzle et al. 2017, Filgueira et al. 2017).

The bay scallop Argopecten irradians (Lamarck, 1819) naturally occurs on the eastern coast of the United States (Maine to New Jersey) and historically supported a vibrant, successful fishery until populations began to collapse over the past $30 \mathrm{yr}$. The bay scallop grows best when temperatures are between
18 and $28^{\circ} \mathrm{C}$ and ceases to grow below $5^{\circ} \mathrm{C}$ (Wang \& Wang 2008). In the 1980 s, bay scallops were introduced to both Canada and China (Zhang 1986), achieving great success in China with an annual production of 300000 tonnes in 1994.

With such profitable vast development of intensive mariculture, there is an obvious need to examine potential effects within localized coastal zones. To date, studies on biodeposition of particulate nutrients and trace elements by filter-feeding bivalves in coastal waters are still lacking, especially for trace elements. It is well known that physiological rates (clearance rate, oxygen consumption rate and ammonia excretion rate) respond allometrically with the tissue dry weight (DW) of suspension-feeding bivalves (Bayne \& Newell 1983). However, it is not known whether biodeposition rates also respond in a similar way. The aims of this study were to determine (1) whether the biodeposition rates respond exponentially with the tissue DW of filter-feeding bivalves and (2) whether the suspension-cultured rapid growing bay scallop Argopecten irradians could markedly influence the sedimentation of total particulate matter, particulate biogenic elements $(C, N, P)$ and trace elements ( $\mathrm{Cu}, \mathrm{Zn}, \mathrm{Pb}, \mathrm{Cr}, \mathrm{Cd}, \mathrm{Hg}, \mathrm{As})$.

\section{MATERIALS AND METHODS}

\section{Study area}

Laizhou Bay (Fig. 1) is located in the northwest of the Shandong Peninsula, northern China, and covers a total area of approx. $7000 \mathrm{~km}^{2}$, with a mean depth of $9 \mathrm{~m}$. In the west zone of the bay, the Yellow River (Huanghe River in Fig. 1), the $6^{\text {th }}$ longest river in the world, empties into the bay. Laizhou Bay is listed as a frequently occurring 'red tide' area for coastal Chinese waters (Huang et al. 2003). The nutrient regime of Laizhou Bay has experienced a dramatic change in the past $30 \mathrm{yr}$, with a 10-fold increase in dissolved inorganic nitrogen concentrations, alongside an equivalent 10-fold decrease in dissolved inorganic phosphorus levels (Zhang et al. 2014). The major component of dissolved inorganic nitrogen also changed from $\mathrm{NH}_{4}-\mathrm{N}$ to $\mathrm{NO}_{3}-\mathrm{N}$ due to excessive anthropogenic nitrogen input (Shan et al. 2000). In addition, the heavy metal pollution in Laizhou Bay raised great concerns which prompted numerous investigations ( $\mathrm{Hu}$ et al. 2011, Gao et al. 2013, Wu et al. 2014). It has been reported that a total of 1000 tonnes of $\mathrm{Cu}, \mathrm{Pb}, \mathrm{Zn}, \mathrm{Cr}, \mathrm{As}$ and $\mathrm{Hg}$ have drained into this region from riverine sources (NCSB 2011). Sediments and organisms with 


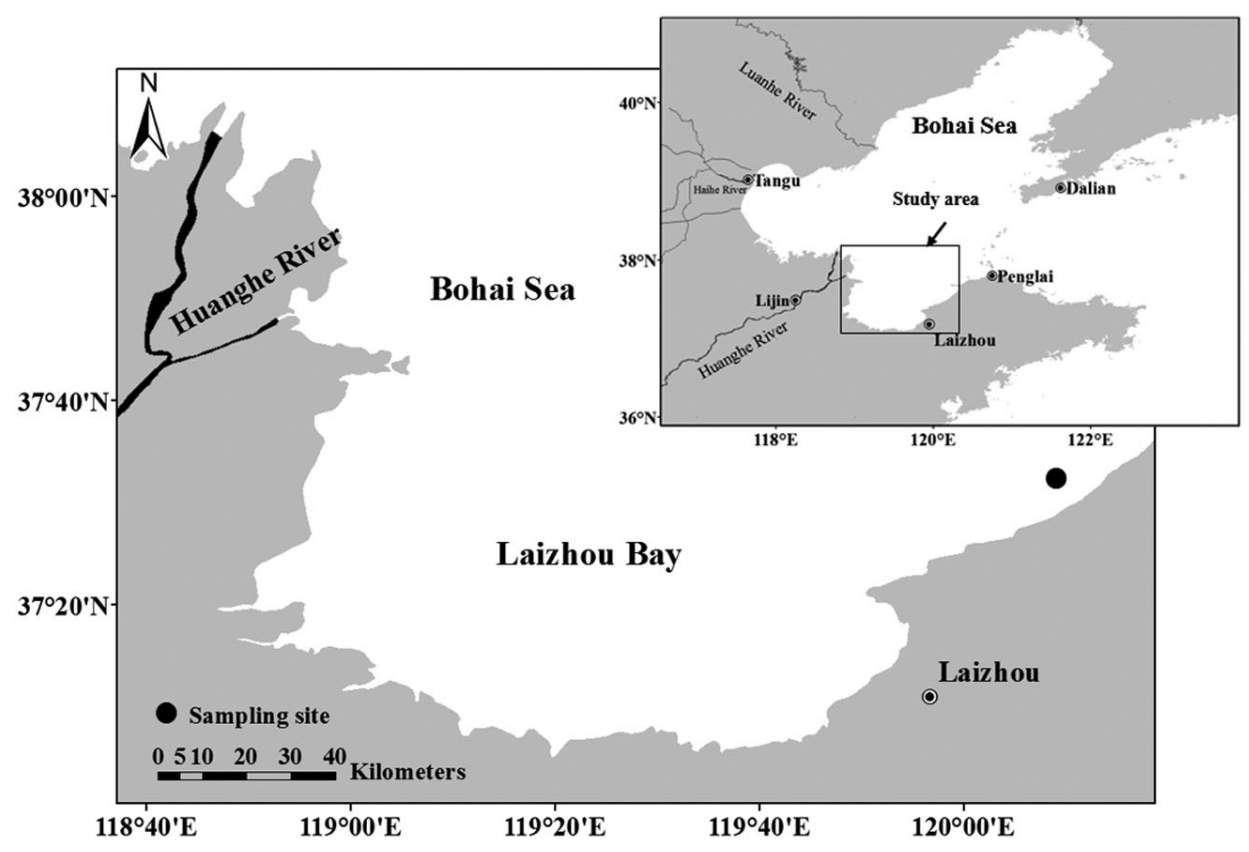

Fig. 1. Location of experimental site in Laizhou Bay $(\bullet)$, northern China

excessive trace metal concentrations have been found in this region (NMEB 2009, Zhuang \& Gao 2013).

Scallop mariculture in Laizhou Bay started in the late 1980s and has lasted for almost 30 yr. The suspension longline culture area is concentrated along a thin strip in the south bay, extending from Sanshandao Town to Zhaoyuan Town in Yantai City, covering a total area of 534 ha and supporting a culture density of approx. 200 ind. $\mathrm{m}^{-2}$ (Liu et al. 2004). The growing period for scallops in the bay is about $5 \mathrm{mo}$. Numerous investigations were conducted in the late 1990s to study the hydrology (Zhao \& Chen 2001), nutrient distributions and seasonal variations $(\mathrm{Qu}$ et al. 2002, Liu et al. 2004), phytoplankton ecology (Chen et al. 2001, Liu et al. 2004) and seston dynamics (Liang et al. 2001) of the bay.

The current study was specifically focused on the bay scallop mariculture area of Laizhou Bay $\left(37^{\circ} 30^{\prime}\right.$ $12^{\prime \prime} \mathrm{N}, 120^{\circ} 10^{\prime} 36^{\prime \prime} \mathrm{E}$ ) and was carried out over a $3 \mathrm{mo}$ period from September to December 2013. The mean seawater semi-exchange period of this study area was $74 \mathrm{~d}$ (in autumn) (Zhao \& Chen 2001). Seston in these mariculture waters was of high quality (Liang et al. 2001), with diatoms dominating the phytoplankton community during the scallops' rapid growth period (Liu et al. 2004). The surface sediments of Laizhou Bay were found to be of high quality and unlikely to cause negative effects on the ecosystem (Gao et al. 2013), but related research by Zhang et al. (2013) found that the macrobenthic com- munities in Laizhou Bay were probably negatively affected by the trace elements in the surrounding sediments.

\section{Biodeposition}

Biodeposition was determined using sediment traps (Fig. 2) that were modified based on our previous study (Zhou et al. 2006a). The research involved

Fig. 2. PVC cylindrical trap developed for the collection of bay scallop biodeposits. The trap was attached to and suspended under the longline used for scallop culture
Floats

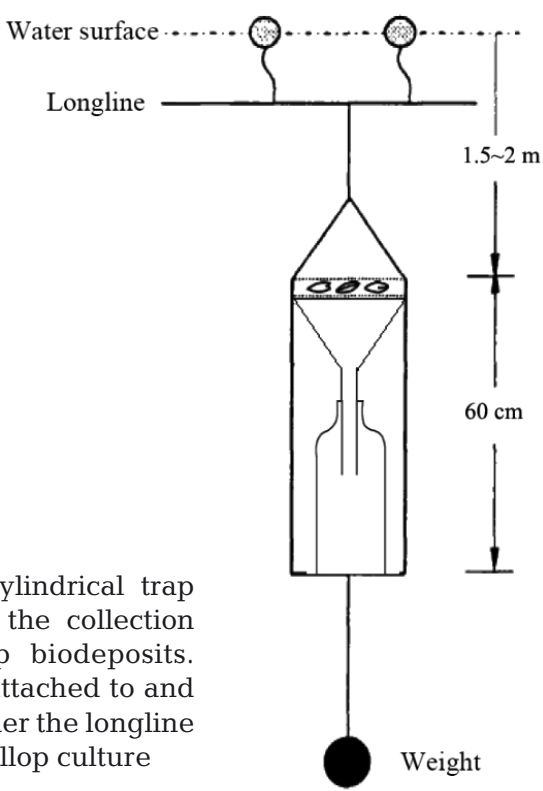


4 separate treatments (based on size) with 4 replicates each. One treatment was designed for small scallops (5 ind. $\operatorname{trap}^{-1}$ ), the second for medium scallops (4 ind. $\operatorname{trap}^{-1}$ ), the third for big scallops ( 3 ind. $\operatorname{trap}^{-1}$ ) and the fourth contained only scallop shells, acting as a control. The shell height of small scallops was $47.87 \pm 3.43 \mathrm{~mm}$ (tissue DW $0.91 \pm 0.39 \mathrm{~g} \mathrm{ind.}^{-1}$ ), medium scallops, $56.38 \pm 2.08 \mathrm{~mm}(1.54 \pm 0.48 \mathrm{~g}$ ind $\left.^{-1}\right)$ and big scallops $64.73 \pm 6.14 \mathrm{~mm}(2.64 \pm 1.07 \mathrm{~g}$ ind. ${ }^{-1}$ ). The top of each sediment trap was covered by 2 nets (20 mm mesh), and set apart by $70 \mathrm{~mm}$. Natural sedimented material and any biodeposits produced by scallops were collected in all traps. Biodeposition rate $\left(B D R ; g\right.$ ind..$^{-1} \mathrm{~d}^{-1}$ ) was measured based on the amount of material collected from each trap containing animals, as well as that from the control. In the beginning, scallops were randomly selected from a culture site in Laizhou Bay, and their shell surfaces were cleaned to remove any fouling epibiota and other materials. During the experiment, the scallops were placed evenly between the nets of the sediment traps. Since the scallops in September were relatively small, they were divided into 2 size categories (small [S] and medium [M]), while in October and November, scallops were divided into 3 size categories: small, medium and big (B).

All sediment traps were suspended from an empty longline (Fig. 2) with no scallops cultured within a radius of $10 \mathrm{~m}$, so that the experimental animals were at a depth of ca. $2 \mathrm{~m}$, corresponding to a routine depth for scallops cultivated in lantern nets. After the traps had been deployed for approximately $5 \mathrm{~d}$, they were retrieved from a boat. The polypropylene bottles inside the traps were transported to the laboratory, where excess water in the sediment was siphoned out and the collected material was rinsed 3 times with distilled water to remove salts. The weight of sediment collected in each bottle was determined following oven drying of the material at $60^{\circ} \mathrm{C}$ for $4 \mathrm{~d}$, and then the sedimented material was ground to a fine powder $(80 \mathrm{mesh})$. Shell height $( \pm 0.01 \mathrm{~mm})$ of scallops in each trap was determined and dry weight of soft tissue was measured by drying at $60^{\circ} \mathrm{C}$ to constant weight $( \pm 0.01 \mathrm{~g})$.

In addition, clearance rate (CR) was indirectly estimated from biodeposition rates (Iglesias et al. 1998,Cranford \& Hill 1999, Yu et al. 2017), by using the inorganic matter (ash) in biodeposits as a quantitative tracer of the filtered material. The relationships between physiological rates (BDR and CR) and tissue DW were modeled using the allometric equation: $\mathrm{BDR} / \mathrm{CR}=a W^{b}$, where $W$ is the tissue DW of bay scallop, constant $b$ is the weight exponent and $a$ is the rate for a scallop of $1 \mathrm{~g}$ tissue DW. In order to preclude variability in physiological rates owing to size difference, the physiological rates (BDR and $C R$ ) were standardized to an equivalent individual based on the following formula: $Y_{\mathrm{s}}=Y_{\mathrm{e}} \times\left(W_{\mathrm{s}} / W_{\mathrm{e}}\right)^{b}$; where $Y_{\mathrm{s}}$ represents the physiological rate for a standardized individual, $Y_{\mathrm{e}}$ is the uncorrected (measured) physiological rate, $W_{\mathrm{s}}$ is the standard tissue DW (0.91 $\mathrm{g}$ for small scallops, $1.54 \mathrm{~g}$ for medium scallops and $2.64 \mathrm{~g}$ for big scallops), and $W_{\mathrm{e}}$ is the observed tissue DW weight of an experimental individual.

\section{Water column}

Environmental parameters, including temperature, salinity, $\mathrm{pH}$ and chlorophyll a ( $\mathrm{chl}$ a) were examined by Yellow Spring Instruments (YSI 6600). Surface water samples were collected twice every day (08:00 and 16:00 h) for 2 to $4 \mathrm{~d}$ (depending on weather conditions during each sampling month) at a depth of $2 \mathrm{~m}$, and immediately filtered to measure total suspended particulate matter (TPM), particulate organic material (POM), particulate inorganic material (PIM), particulate carbon (POC), particulate nitrogen (PON) and particulate phosphorus (PP) concentrations. For determination of POM and PIM, 11 of each sample was filtered through a pre-weighed and pre-ignited $\left(450^{\circ} \mathrm{C}\right.$ for $6 \mathrm{~h}$ ) GF/F glass fiber filter. The filter was then rinsed with $50 \mathrm{ml}$ of distilled water to remove salts, dried at $60^{\circ} \mathrm{C}$ for $24 \mathrm{~h}$ and then weighed. The filter was later ignited at $450^{\circ} \mathrm{C}$ for $6 \mathrm{~h}$. For determination of POC and PON, 0.21 of each sample was filtered through a GF/F glass fiber filter. The filter was dried at $60^{\circ} \mathrm{C}$ for $24 \mathrm{~h}$ and then analyzed with a CHN analyzer (Model 240c; Perkin Elmer) standardized with acetanilide. PP was measured by means of a modified method that followed Solórzano \& Sharp (1980) for determination of PP (Zhou et al. 2003, 2006a). In addition, the collected water samples were analyzed for nutrients, including dissolved inorganic nitrogen (DIN; $\mathrm{NO}_{3}-\mathrm{N}$, $\mathrm{NO}_{2}-\mathrm{N}, \mathrm{NH}_{4}-\mathrm{N}$ ) and dissolved inorganic phosphorus (DIP; $\left.\mathrm{PO}_{4}-\mathrm{P}\right)$. The nutrients were determined with an automatic nutrient analyzer (Skalar San Plus System).

\section{Analysis of organic matter and nutrient elements in sediments}

Subsamples of the dried sedimented material were used to determine the concentration of organic matter $(\mathrm{OM})$ by igniting $\left(500^{\circ} \mathrm{C}\right.$ for $\left.4 \mathrm{~h}\right)$ dried and preweighed samples. Subsamples of soft tissue and sed- 
iments from the traps were pre-treated with $0.2 \mathrm{~mol}$ $\mathrm{1}^{-1} \mathrm{HCl}$ to remove carbonates and then analyzed for organic carbon (OC) and total nitrogen (TN) with a CHN analyzer (Model 240c; Perkin Elmer) standardized with acetanilide. Total phosphorus (TP) and organic phosphorus (OP) concentrations of subsamples were also analyzed by means of a modified method that followed Solórzano \& Sharp (1980) for particulate P determination (Zhou et al. 2003, 2006a).

\section{Analysis of trace elements in sediments and scallops}

Trace elements of $\mathrm{Cu}, \mathrm{Zn}, \mathrm{Pb}, \mathrm{Cr}, \mathrm{Cd}, \mathrm{Hg}$ and $\mathrm{As}$ in the sedimented material and scallop soft tissue were determined with the analytical procedure described in Wang et al. (2017) for sediment and organism, respectively. Trace elements in scallop shells were measured using the same analytical procedure as sediment.

\section{Statistical analysis}

Data are presented as means \pm SD. OM, biogenic and trace element concentrations are provided on dry weight basis. Differences in OM, biogenic and trace element concentrations within sediments between different treatments were analyzed using 1-way analysis of variance (ANOVA). Differences among different months were also analyzed using ANOVA. Prior to statistical analysis, data were examined for normality of distribution and homogeneity of variance with Kolmogorov-Smirnov test and Levene's test, respectively. A statistical significance level of 0.05 was used. Statistical analyses were carried out using the software $\mathrm{R}$ v.1.0 for Windows (R Development Core Team 2016).

\section{RESULTS}

\section{Water column characteristics}

The monthly variations of physical and chemical parameters and particulate trace element concentrations of surface waters at our experimental site in Laizhou Bay are shown in Table 1. During the study period, the sea surface temperature decreased from $23.38^{\circ} \mathrm{C}$ in September to $16.94^{\circ} \mathrm{C}$ in October and $9.50^{\circ} \mathrm{C}$ in November. Salinity was stable, ranging from 27.69 to 28.91. Chl a concentrations were low, ranging from 1.12 to $2.27 \mu \mathrm{g} \mathrm{l}^{-1}$, lower than concentrations recorded in October 1997 (3.2 $\mu \mathrm{g} \mathrm{l}^{-1}$; Liang et al. 2001). TPM varied markedly during the study period, with values in October $\left(17.75 \pm 6.87 \mathrm{mg} \mathrm{l}^{-1}\right) 2$ times greater than concentrations recorded in either September $\left(5.97 \pm 2.23 \mathrm{mg} \mathrm{l}^{-1}\right)$ or November $(7.52 \pm$ $1.66 \mathrm{mg} \mathrm{l}^{-1}$ ). The OM proportion was high in September $(56.37 \pm 7.41 \%)$, followed by a dramatic 3 -fold decline in October and November. The concentrations of DIN ranged from 15.08 to $36.86 \mu \mathrm{mol} \mathrm{l}^{-1}$ (mean: $23.28 \mu \mathrm{mol} \mathrm{l}^{-1}$ ); these values were higher than those recorded in 1997 (6.35 to $18.6 \mathrm{mmol}^{-1}$; Qu et al. 2002). $\mathrm{NO}_{3}-\mathrm{N}$ constituted the major part (62.20 to $89.97 \%$ ) of DIN. The concentrations of DIP ranged from 0.06 to $0.20 \mu_{\mathrm{mol}}{ }^{-1}$ (mean: $0.11 \mu \mathrm{mol}{ }^{-1}$ ), which were remarkably lower than values recorded in 1997 (0.41 to $0.85 \mu \mathrm{mol} \mathrm{l}^{-1}$; Qu et al. 2002).

\section{Nutrient composition and trace element concentrations in bay scallop tissue}

There were no significant differences in the C, N and $\mathrm{P}$ concentrations of scallop tissue between differ-

Table 1. Mean $( \pm \mathrm{SD})$ monthly variations of environmental factors and concentrations of particulate material and trace elements of surface waters at the experimental site in Laizhou Bay. T: temperature; S: salinity; TPM: total particulate matter; POM: particulate organic matter; OM: organic matter; POC: particulate organic carbon; PON: particulate organic nitrogen; PP: particulate phosphorus; $\mathrm{Chl}$ a: chlorophyll a

\begin{tabular}{|c|c|c|c|c|c|c|c|c|}
\hline Time & $\begin{array}{c}T \\
\left({ }^{\circ} \mathrm{C}\right)\end{array}$ & $\begin{array}{c}\mathrm{S} \\
(\mathrm{ppt})\end{array}$ & $\begin{array}{c}\text { TPM } \\
\left(\mathrm{mg} \mathrm{l}^{-1}\right)\end{array}$ & $\begin{array}{c}\mathrm{POM} \\
\left(\mathrm{mg} \mathrm{l}^{-1}\right)\end{array}$ & $\begin{array}{l}\text { OM } \\
(\%)\end{array}$ & $\begin{array}{c}\text { POC } \\
\left(\mu \mathrm{g} \mathrm{l}^{-1}\right)\end{array}$ & $\begin{array}{c}\text { PON } \\
\left(\mu \mathrm{g} \mathrm{l}^{-1}\right)\end{array}$ & $\begin{array}{c}P P \\
\left(\mu \mathrm{g} \mathrm{l}^{-1}\right)\end{array}$ \\
\hline Sep & $23.38 \pm 0.98$ & $27.70 \pm 0.25$ & $5.97 \pm 2.23$ & $3.27 \pm 0.80$ & $56.37 \pm 7.41$ & $412.5 \pm 103.2$ & $63.4 \pm 16.3$ & $4.08 \pm 0.77$ \\
\hline Oct & $16.94 \pm 0.17$ & $28.91 \pm 0.13$ & $17.75 \pm 6.87$ & $3.40 \pm 1.24$ & $19.58 \pm 2.39$ & $394.4 \pm 127.6$ & $49.3 \pm 12.6$ & $4.17 \pm 1.39$ \\
\hline \multirow[t]{2}{*}{ Nov } & $9.50 \pm 0.14$ & $27.69 \pm 0.25$ & $7.52 \pm 1.66$ & $1.38 \pm 0.31$ & $18.79 \pm 4.04$ & $431.0 \pm 92.7$ & $93.3 \pm 34.1$ & $5.63 \pm 0.71$ \\
\hline & $\begin{array}{c}\text { Chl a } \\
\left(\mu \mathrm{g} \mathrm{l}^{-1}\right)\end{array}$ & $\begin{array}{c}\text { As } \\
\left(\mathrm{ng} \mathrm{l}^{-1}\right)\end{array}$ & $\begin{array}{c}\mathrm{Cd} \\
\left(\mathrm{ng} \mathrm{l}^{-1}\right)\end{array}$ & $\begin{array}{c}\mathrm{Cr} \\
\left(\mathrm{ng} \mathrm{l}^{-1}\right)\end{array}$ & $\begin{array}{c}\mathrm{Cu} \\
\left(\mathrm{ng} \mathrm{l}^{-1}\right)\end{array}$ & $\underset{\left(\mathrm{ng} \mathrm{l}^{-1}\right)}{\mathrm{Zn}}$ & $\begin{array}{c}\mathrm{Pb} \\
\left(\mathrm{ng} \mathrm{l}^{-1}\right)\end{array}$ & $\begin{array}{c}\mathrm{Hg} \\
\left(\mathrm{ng} \mathrm{l}^{-1}\right)\end{array}$ \\
\hline Sep & $2.26 \pm 0.25$ & $0.25 \pm 0.00$ & $1.41 \pm 0.03$ & $0.46 \pm 0.00$ & $0.24 \pm 0.01$ & $0.70 \pm 0.02$ & $0.58 \pm 0.25$ & $3.40 \pm 0.28$ \\
\hline Oct & $1.12 \pm 0.53$ & $0.29 \pm 0.01$ & $1.94 \pm 0.71$ & $0.36 \pm 0.02$ & $0.20 \pm 0.01$ & $0.49 \pm 0.01$ & $0.20 \pm 0.02$ & $3.08 \pm 0.06$ \\
\hline Nov & $2.27 \pm 0.87$ & $0.15 \pm 0.05$ & $1.03 \pm 0.23$ & $0.26 \pm 0.01$ & $0.10 \pm 0.01$ & $0.45 \pm 0.01$ & $0.06 \pm 0.01$ & $1.38 \pm 0.16$ \\
\hline
\end{tabular}


Table 2. Mean $( \pm \mathrm{SD})$ biogenic element composition in bay scallop Argopecten irradians tissue. S: small size scallop; M: medium size; B: big size. Different lowercase letters in the same month indicate significant differences $(p<0.05)$. Different uppercase letters among different months indicate significant differences $(\mathrm{p}<0.05)$

\begin{tabular}{|clccc|}
\hline Time & Size & C $(\%)$ & N $(\%)$ & P $(\%)$ \\
\hline Sep & S & $43.89 \pm 1.03^{\mathrm{a}}$ & $12.14 \pm 0.20^{\mathrm{a}}$ & $11.22 \pm 1.33^{\mathrm{a}}$ \\
& M & $43.24 \pm 1.57^{\mathrm{a}}$ & $11.99 \pm 0.31^{\mathrm{a}}$ & $11.61 \pm 1.36^{\mathrm{a}}$ \\
& Mean & $43.57 \pm 1.24^{\mathrm{A}}$ & $12.06 \pm 0.25^{\mathrm{B}}$ & $11.42 \pm 1.22^{\mathrm{B}}$ \\
Oct & S & $43.53 \pm 0.34^{\mathrm{a}}$ & $10.94 \pm 0.30^{\mathrm{a}}$ & $11.86 \pm 0.35^{\mathrm{a}}$ \\
& M & $43.96 \pm 0.54^{\mathrm{a}}$ & $10.96 \pm 0.23^{\mathrm{a}}$ & $11.57 \pm 0.59^{\mathrm{a}}$ \\
& $\mathrm{B}$ & $43.90 \pm 0.91^{\mathrm{a}}$ & $10.61 \pm 0.24^{\mathrm{a}}$ & $12.31 \pm 0.11^{\mathrm{a}}$ \\
Mean & $43.80 \pm 0.59^{\mathrm{A}}$ & $10.84 \pm 0.28^{\mathrm{A}}$ & $11.91 \pm 0.47^{\mathrm{B}}$ \\
Nov & S & $45.44 \pm 0.77^{\mathrm{a}}$ & $11.12 \pm 0.16^{\mathrm{a}}$ & $9.37 \pm 1.28^{\mathrm{a}}$ \\
& M & $42.65 \pm 3.69^{\mathrm{a}}$ & $10.44 \pm 0.95^{\mathrm{a}}$ & $8.53 \pm 1.12^{\mathrm{a}}$ \\
& $\mathrm{B}$ & $41.01 \pm 4.65^{\mathrm{a}}$ & $9.99 \pm 0.94^{\mathrm{a}}$ & $10.13 \pm 0.16^{\mathrm{a}}$ \\
Mean & $43.22 \pm 3.48^{\mathrm{A}}$ & $10.56 \pm 0.83^{\mathrm{A}}$ & $9.34 \pm 1.10^{\mathrm{A}}$ \\
\hline
\end{tabular}

ent sizes, within each month (1-way ANOVA, $\mathrm{p}>0.05$; Table 2). However, the N tissue concentrations in September were significantly higher than in October and November (1-way ANOVA, p < 0.05) and the P concentrations in September and October were significantly higher than in November ( $\mathrm{p}<0.05$; Table 2 ). No significant differences were found for $\mathrm{C}$ concentrations over the 3 mo period ( $p>0.05$ ). Results showed that the $\mathrm{N}$ concentration of scallop tissue varied more than that of $\mathrm{C}_{i}$ similar findings were recorded in a study on the Pacific oyster Crassostrea gigas (Bayne 2009). Levels of trace elements in the scallop tissue (Table 3 ) differed markedly from those found in the shell $(\mathrm{p}<0.001)$. The concentrations of $\mathrm{As}, \mathrm{Cd}, \mathrm{Cu}, \mathrm{Pb}$, $\mathrm{Zn}$ and $\mathrm{Hg}$ in the flesh were dozens of times higher than concentrations in the shell $(p<0.001)$ and on the contrary, the concentrations of $\mathrm{Cr}$ in the flesh were significantly lower than in the shell $(p<0.001)$. Thus, we can infer that trace element concentrations vary in scallop tissue anatomy. There were no significant differences in trace element concentrations either in tissue or shell among sizes ( $p>0.05$ ).

\section{Biodeposition rate and its relationship with the tissue DW of the bay scallop}

The biodeposition rates of scallops of different sizes during the study period ranged from 0.84 to $2.03 \mathrm{~g}$ ind. ${ }^{-1} \mathrm{~d}^{-1}$, with higher values generally recorded in the largest size category ( $p<0.001$; Table 4$)$. The allometric relationship between biodeposition rates and dry weight is shown in Table 5. It was obvious that the allometric relationship ceased to exist when water temperatures dropped below $10^{\circ} \mathrm{C}$, when the scallops were harvested; this phenomenon may be due to a change in their physiological status, energy demand and/or allocation among individuals of different sizes. The average daily biodeposition rates expressed as $\mathrm{g}$ ( $\mathrm{g}$ tissue $\mathrm{DW})^{-1} \mathrm{~d}^{-1}$ were $1.24 \mathrm{~g}$ (g tissue $\mathrm{DW})^{-1} \mathrm{~d}^{-1}$ in September and $0.96 \mathrm{~g}$ (g tissue DW $)^{-1} \mathrm{~d}^{-1}$ in October.

\section{Biogeochemical characteristics of the sediments from the traps}

Generally, the concentrations of OM, TC, TN, TP and $\mathrm{OP}$ in sediments from the control traps were

Table 3. Trace element ( $\mathrm{As}, \mathrm{Cd}, \mathrm{Cr}, \mathrm{Cu}, \mathrm{Zn}, \mathrm{Pb}$ and $\mathrm{Hg}$ ) concentrations in tissue and shells of small (S), medium (M) and big (B) sized bay scallops

\begin{tabular}{|c|c|c|c|c|c|c|c|c|c|}
\hline & Time & Size & $\begin{array}{c}\mathrm{As} \\
\left(\mathrm{mg} \mathrm{kg}^{-1}\right)\end{array}$ & $\begin{array}{c}\mathrm{Cd} \\
\left(\mathrm{mg} \mathrm{kg}^{-1}\right)\end{array}$ & $\begin{array}{c}\mathrm{Cr} \\
\left(\mathrm{mg} \mathrm{kg}^{-1}\right)\end{array}$ & $\begin{array}{c}\mathrm{Cu} \\
\left(\mathrm{mg} \mathrm{kg}^{-1}\right)\end{array}$ & $\begin{array}{c}\mathrm{Pb} \\
\left(\mathrm{mg} \mathrm{kg}^{-1}\right)\end{array}$ & $\begin{array}{c}\mathrm{Zn} \\
\left(\mathrm{mg} \mathrm{kg}^{-1}\right)\end{array}$ & $\begin{array}{c}\mathrm{Hg} \\
\left(\mu \mathrm{kg}^{-1}\right)\end{array}$ \\
\hline \multirow[t]{8}{*}{ Tissue } & Sep & $\mathrm{S}$ & 9.760 & 14.93 & 0.803 & 115.6 & 8.862 & 548.1 & 487 \\
\hline & & M & 7.525 & 15.57 & 0.793 & 131.5 & 6.984 & 868.8 & 334 \\
\hline & Oct & $\mathrm{S}$ & 12.631 & 15.19 & 0.712 & 100.4 & 8.236 & 737.1 & 319 \\
\hline & & $\mathrm{M}$ & 11.432 & 13.76 & 0.494 & 74.56 & 6.734 & 513.7 & 289 \\
\hline & & B & 10.304 & 14.60 & 0.345 & 90.1 & 8.351 & 656.8 & 274 \\
\hline & Nov & $\mathrm{S}$ & 7.800 & 16.92 & 0.232 & 32.17 & 4.689 & 484.7 & 152 \\
\hline & & $\mathrm{M}$ & 7.773 & 16.11 & 0.341 & 28.13 & 4.131 & 367.7 & 151 \\
\hline & & B & 6.935 & 16.17 & 0.189 & 27.04 & 3.977 & 486.4 & 156 \\
\hline \multirow[t]{5}{*}{ Shell } & Sep & M & 0.074 & 0.012 & 17.65 & 1.417 & 0.358 & 0.554 & 42.9 \\
\hline & Oct & $\mathrm{S}$ & 0.218 & 0.045 & 18.13 & 2.552 & 1.756 & 2.952 & 60.7 \\
\hline & & M & 0.109 & 0.058 & 10.12 & 1.922 & 0.544 & 2.435 & 28.7 \\
\hline & & B & 0.129 & 0.080 & 10.36 & 2.053 & 1.019 & 1.450 & 53.2 \\
\hline & Nov & M & 0.123 & 0.110 & 3.393 & 1.799 & 1.423 & 1.517 & 32.3 \\
\hline
\end{tabular}


Table 4. Tissue dry weight ( $W$ ) and biodeposition rate (BDR) of bay scallop Argopecten irradians in different months. S: small size scallops; M: medium size; B: big size. Different letters in the same month and column indicate significant differences $(p<0.05)$

\begin{tabular}{|cccc|}
\hline Time & Size & $\begin{array}{c}W \\
\text { (g ind }^{-1} \text { ) }\end{array}$ & $\begin{array}{c}\text { BDR } \\
\left(\text { g ind }^{-1} \text { d }^{-1} \text { ) }\right.\end{array}$ \\
\hline Sep & S & $0.63 \pm 0.04^{\mathrm{a}}$ & $0.96 \pm 0.15^{\mathrm{a}}$ \\
& $\mathrm{M}$ & $1.19 \pm 0.18^{\mathrm{b}}$ & $1.37 \pm 0.26^{\mathrm{b}}$ \\
Oct & $\mathrm{S}$ & $0.74 \pm 0.07^{\mathrm{a}}$ & $0.84 \pm 0.13^{\mathrm{a}}$ \\
& $\mathrm{M}$ & $1.33 \pm 0.06^{\mathrm{b}}$ & $1.07 \pm 0.16^{\mathrm{b}}$ \\
& $\mathrm{B}$ & $1.88 \pm 0.07^{\mathrm{c}}$ & $1.60 \pm 0.11^{\mathrm{c}}$ \\
Nov & $\mathrm{S}$ & $1.35 \pm 0.09^{\mathrm{a}}$ & $1.17 \pm 0.19^{\mathrm{a}}$ \\
& $\mathrm{M}$ & $2.09 \pm 0.11^{\mathrm{b}}$ & $2.03 \pm 0.20^{\mathrm{b}}$ \\
& $\mathrm{B}$ & $3.39 \pm 0.36^{\mathrm{b}}$ & $1.23 \pm 0.07^{\mathrm{c}}$ \\
\hline
\end{tabular}
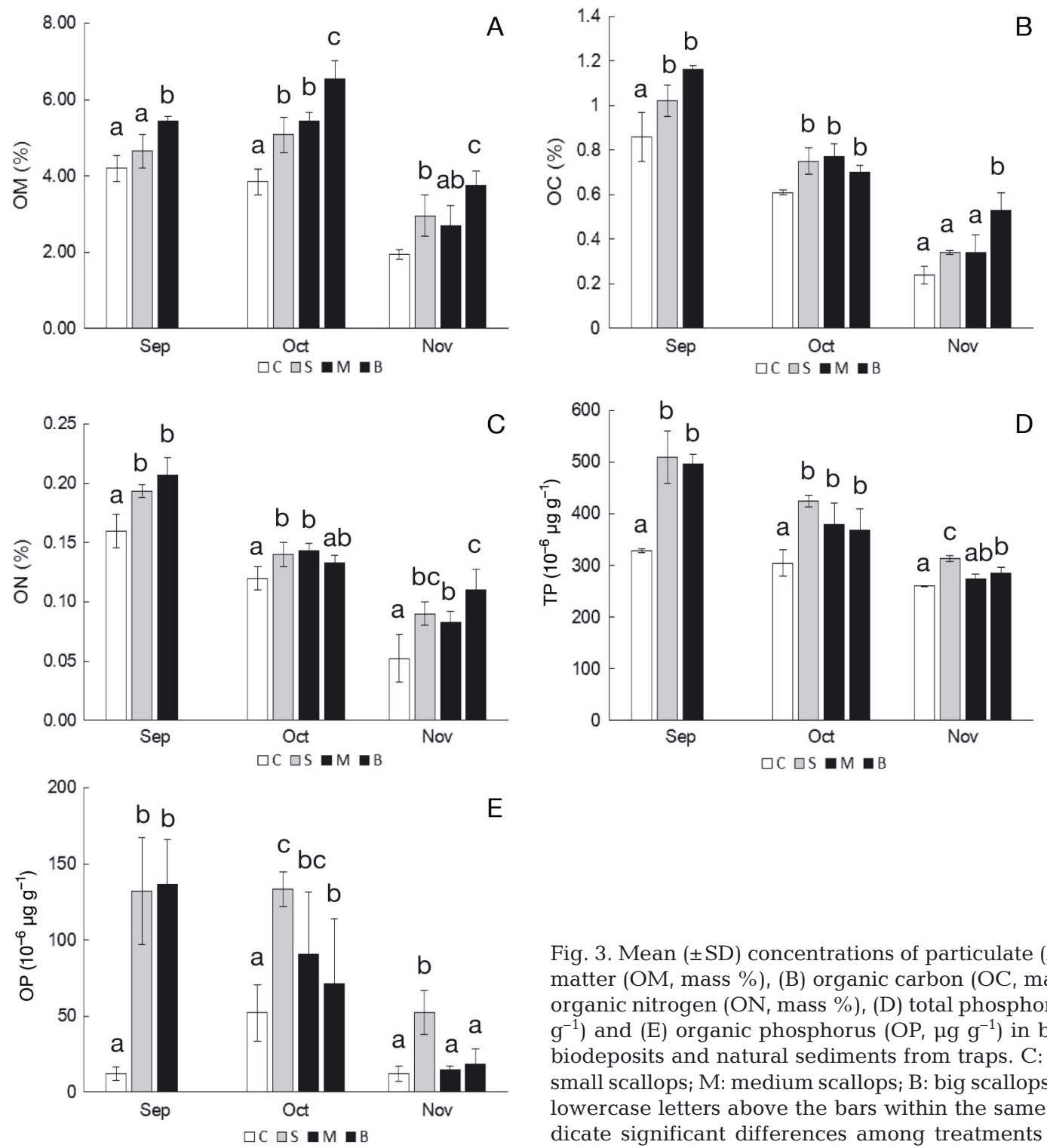

Table 5. Allometric relationships for biodeposition rates for different months in bay scallop Argopecten irradians. a: the coefficient indicating the biodeposition rate for a scallop of $1 \mathrm{~g}$ soft tissue dry weight; $b$ : the weight exponent. ${ }^{* *} \mathrm{p}<0.01$

\begin{tabular}{|ccccc|}
\hline Time & $a$ & $b$ & $\mathrm{R}^{2}$ & $F$ \\
\hline Sep & 1.24 & 0.55 & 1.00 & $26.52^{* *}$ \\
Oct & 0.96 & 0.66 & 0.92 & $\begin{array}{c}37.67^{* *} \\
0.15\end{array}$ \\
\hline Nov & 1.40 & 0.03 & 0.00 & \\
\hline
\end{tabular}

significantly lower than concentrations found in the experimental traps (Fig. 3), which indicated that the biodeposition of bay scallop may in fact be contributing to the enrichment of these substances in the sediment.

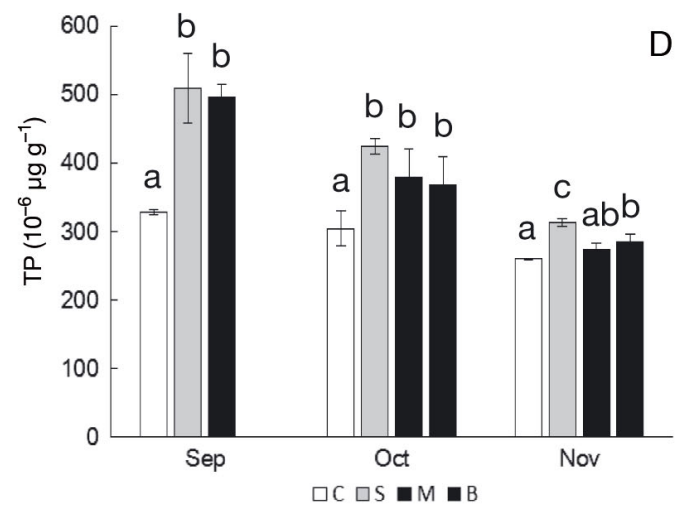

Fig. 3. Mean $( \pm \mathrm{SD})$ concentrations of particulate (A) organic matter (OM, mass \%), (B) organic carbon (OC, mass \%), (C) organic nitrogen (ON, mass \%), (D) total phosphorus (TP, $\mu \mathrm{g}$ $\mathrm{g}^{-1}$ ) and (E) organic phosphorus (OP, $\mu \mathrm{g} \mathrm{g}^{-1}$ ) in bay scallop biodeposits and natural sediments from traps. C: control; $\mathrm{S}$ : small scallops; M: medium scallops; B: big scallops. Different lowercase letters above the bars within the same month indicate significant differences among treatments $(p<0.05)$ 
Table 6. Mean $( \pm \mathrm{SD})$ trace element concentrations of the sediment from traps in Laizhou Bay ( $\left.\mu \mathrm{g} \mathrm{g}^{-1}\right)$. C: control; S: small size scallop; M: medium size; B: big size. Different letters in the same month and column indicate significant differences $(\mathrm{p}<0.05)$

\begin{tabular}{|c|c|c|c|c|c|c|c|c|}
\hline Time & Size & As & $\mathrm{Cd}$ & $\mathrm{Cr}$ & $\mathrm{Cu}$ & $\mathrm{Zn}$ & $\mathrm{Pb}$ & $\mathrm{Hg}$ \\
\hline \multirow[t]{3}{*}{ Sep } & $\mathrm{C}$ & $32.34 \pm 0.28^{\mathrm{a}}$ & $0.184 \pm 0.003^{\mathrm{a}}$ & $60.69 \pm 0.16^{\mathrm{b}}$ & $31.58 \pm 0.95^{\mathrm{a}}$ & $91.49 \pm 3.26^{\mathrm{a}}$ & $19.14 \pm 1.14^{\mathrm{a}}$ & $0.445 \pm 0.037^{\mathrm{a}}$ \\
\hline & $\mathrm{S}$ & $29.72 \pm 0.20^{\mathrm{a}}$ & $0.183 \pm 0.004^{\mathrm{a}}$ & $85.93 \pm 5.79^{c}$ & $31.92 \pm 0.72^{\mathrm{a}}$ & $96.34 \pm 4.41^{\mathrm{a}}$ & $18.08 \pm 1.93^{\mathrm{a}}$ & $0.391 \pm 0.004^{\mathrm{a}}$ \\
\hline & M & $28.33 \pm 10.31^{\mathrm{a}}$ & $0.283 \pm 0.035^{\mathrm{b}}$ & $47.31 \pm 6.48^{\mathrm{a}}$ & $28.66 \pm 4.53^{\mathrm{a}}$ & $102.26 \pm 12.06^{\mathrm{a}}$ & $14.62 \pm 3.68^{\mathrm{a}}$ & $0.409 \pm 0.042^{\mathrm{a}}$ \\
\hline \multirow[t]{4}{*}{ Oct } & $\mathrm{C}$ & $25.20 \pm 1.93^{\mathrm{a}}$ & $0.254 \pm 0.093^{\mathrm{a}}$ & $47.28 \pm 2.41^{\mathrm{a}}$ & $25.81 \pm 1.05^{\mathrm{a}}$ & $63.73 \pm 0.76^{\mathrm{a}}$ & $18.08 \pm 1.97^{\mathrm{a}}$ & $0.403 \pm 0.007^{\mathrm{a}}$ \\
\hline & $\mathrm{S}$ & $34.88 \pm 4.46^{\mathrm{b}}$ & $0.197 \pm 0.036^{\mathrm{a}}$ & $102.10 \pm 4.65^{\mathrm{bc}}$ & $29.39 \pm 0.58^{b}$ & $99.11 \pm 29.42^{b}$ & $31.10 \pm 9.88^{b}$ & $0.436 \pm 0.016^{\mathrm{a}}$ \\
\hline & M & $29.36 \pm 5.82^{\mathrm{a}}$ & $0.181 \pm 0.033^{\mathrm{a}}$ & $91.83 \pm 6.80^{\mathrm{b}}$ & $27.787 \pm 0.68^{\mathrm{ab}}$ & $105.39 \pm 15.18^{b}$ & $17.90 \pm 0.17^{\mathrm{a}}$ & $0.445 \pm 0.029^{\mathrm{a}}$ \\
\hline & $\mathrm{B}$ & $25.23 \pm 1.15^{\mathrm{a}}$ & $0.284 \pm 0.116^{\mathrm{a}}$ & $106.62 \pm 10.39^{c}$ & $27.44 \pm 2.42^{\mathrm{ab}}$ & $93.04 \pm 3.17^{\mathrm{ab}}$ & $18.25 \pm 0.04^{\mathrm{a}}$ & $0.342 \pm 0.113^{\mathrm{a}}$ \\
\hline \multirow[t]{4}{*}{ Nov } & $\mathrm{C}$ & $20.22 \pm 4.85^{\mathrm{a}}$ & $0.133 \pm 0.025^{\mathrm{a}}$ & $31.07 \pm 5.74^{\mathrm{a}}$ & $12.56 \pm 1.54^{\mathrm{a}}$ & $51.36 \pm 18.99^{a}$ & $26.76 \pm 3.64^{\mathrm{a}}$ & $0.183 \pm 0.018^{\mathrm{a}}$ \\
\hline & $\mathrm{S}$ & $22.10 \pm 1.01^{\mathrm{ab}}$ & $0.216 \pm 0.079^{b}$ & $38.97 \pm 1.64^{b}$ & $17.96 \pm 0.77^{b}$ & $68.52 \pm 5.32^{\mathrm{ab}}$ & $31.17 \pm 9.69^{a}$ & $0.375 \pm 0.014^{b}$ \\
\hline & M & $24.95 \pm 4.73^{\mathrm{ab}}$ & $0.123 \pm 0.003^{\mathrm{a}}$ & $38.82 \pm 1.37^{\mathrm{b}}$ & $17.29 \pm 1.43^{\mathrm{b}}$ & $67.63 \pm 11.48^{\mathrm{ab}}$ & $32.94 \pm 9.90^{a}$ & $0.374 \pm 0.047^{b}$ \\
\hline & $\mathrm{B}$ & $28.20 \pm 2.92^{\mathrm{b}}$ & $0.232 \pm 0.046^{\mathrm{b}}$ & $40.20 \pm 2.04^{\mathrm{b}}$ & $19.05 \pm 2.73^{b}$ & $89.35 \pm 7.76^{\mathrm{b}}$ & $28.06 \pm 1.69^{a}$ & $0.453 \pm 0.039^{c}$ \\
\hline
\end{tabular}

The trace element concentrations in trap sediments are outlined in Table 6. Trace element concentrations from traps containing scallops were significantly higher than those without scallops (controls), especially during the months of October and November ( $p<$ 0.05). In September, the concentrations of $\mathrm{As}, \mathrm{Cu}, \mathrm{Zn}$, $\mathrm{Pb}$ and $\mathrm{Hg}$ in sediments from the experimental traps were similar to those from the control traps ( $p>0.05)$. However, Cd concentrations in the experimental traps containing medium sized scallops were significantly higher than in the control traps or the traps containing the smaller sized scallops ( $\mathrm{p}<0.05$ ). For $\mathrm{Cr}$, significant differences also exist among sediments from different traps, with small scallops registering the highest concentrations and medium sized scallops the lowest $(\mathrm{p}<$ 0.05). In October and November, nearly all trace element concentrations in the sediments from the traps containing scallops were significantly higher than those from the control traps ( $\mathrm{p}<0.05)$, except for $\mathrm{Hg}$ and $\mathrm{Cd}$ in October and $\mathrm{Pb}$ in November.

\section{Biodeposition rates of organic matter, biogenic elements and trace elements}

Mean biodeposition rates of OM, OC, ON, TP and OP for small scallops were $50.2 \pm 11.4,8.38 \pm 4.55$, $1.72 \pm 0.68,0.51 \pm 0.18$ and $0.160 \pm 0.065 \mathrm{mg}$ ind $^{-1}$ $\mathrm{d}^{-1}$, respectively (Table 7 ). Biodeposition rates of OM, OC, ON and TP for big scallops were significantly higher than small and medium scallops ( $\mathrm{p}<$ 0.05), and there were no significant differences among sampling months ( $\mathrm{p}>0.05)$.

The biodeposition rates of trace elements for bay scallops are shown in Table 8. Biodeposition rates of As, $\mathrm{Cr}, \mathrm{Cu}$, and $\mathrm{Zn}$ for big scallops were significantly higher than small scallops $(\mathrm{p}<0.05)$. In addition, there were no significant differences in biodeposition rates of trace elements among sampling months ( $p>$ 0.05). Negative values for $\mathrm{Cd}$ in September and October should be mentioned, as this could indicate a more intense absorption rate by the scallops.

Table 7. Mean $( \pm \mathrm{SD})$ standardized biodeposition rates for small $(\mathrm{S})$, medium $(\mathrm{M})$ and big (B) bay scallops during different months in Laizhou Bay. TPM: total particulate matter; OM: organic matter; OC: organic carbon; ON: organic nitrogen; TP: total phosphorus; OP: organic phosphorus. Different letters in the same month and column indicate significant differences $(\mathrm{p}<0.05)$

\begin{tabular}{|cccccccc|}
\hline Time & Size & $\begin{array}{c}\text { TPM } \\
\left(\text { ind }^{-1} \mathrm{~d}^{-1}\right)\end{array}$ & $\begin{array}{c}\text { OM } \\
\left(\text { mg ind }^{-1} \mathrm{~d}^{-1}\right)\end{array}$ & $\begin{array}{c}\text { OC } \\
\left(\text { mg ind }^{-1} \mathrm{~d}^{-1}\right)\end{array}$ & $\begin{array}{c}\text { ON } \\
\left(\text { mg ind }^{-1} \mathrm{~d}^{-1}\right)\end{array}$ & $\begin{array}{c}\text { TP } \\
\left(\mathrm{mg} \mathrm{ind}^{-1} \mathrm{~d}^{-1}\right)\end{array}$ & $\begin{array}{c}\text { OP } \\
\left(\mathrm{mg} \mathrm{ind.}^{-1} \mathrm{~d}^{-1}\right)\end{array}$ \\
\hline Sep & $\mathrm{S}$ & $1.21 \pm 0.15^{\mathrm{a}}$ & $58.0 \pm 7.6^{\mathrm{a}}$ & $13.13 \pm 2.58^{\mathrm{a}}$ & $2.49 \pm 0.36^{\mathrm{a}}$ & $0.70 \pm 0.09^{\mathrm{a}}$ & $0.214 \pm 0.053^{\mathrm{a}}$ \\
& $\mathrm{M}$ & $1.60 \pm 0.18^{\mathrm{b}}$ & $94.0 \pm 9.2^{\mathrm{b}}$ & $20.24 \pm 2.35^{\mathrm{b}}$ & $3.58 \pm 0.62^{\mathrm{a}}$ & $0.88 \pm 0.06^{\mathrm{a}}$ & $0.289 \pm 0.086^{\mathrm{a}}$ \\
Oct & $\mathrm{S}$ & $0.95 \pm 0.09^{\mathrm{a}}$ & $55.6 \pm 4.5^{\mathrm{a}}$ & $7.95 \pm 0.81^{\mathrm{a}}$ & $1.44 \pm 0.21^{\mathrm{a}}$ & $0.48 \pm 0.05^{\mathrm{a}}$ & $0.177 \pm 0.031^{\mathrm{a}}$ \\
& $\mathrm{M}$ & $1.17 \pm 0.15^{\mathrm{a}}$ & $73.6 \pm 11.8^{\mathrm{a}}$ & $9.91 \pm 1.06^{\mathrm{a}}$ & $1.82 \pm 0.19^{\mathrm{a}}$ & $0.49 \pm 0.13^{\mathrm{a}}$ & $0.133 \pm 0.087^{\mathrm{a}}$ \\
& $\mathrm{B}$ & $1.98 \pm 0.11^{\mathrm{b}}$ & $153.9 \pm 19.8^{\mathrm{b}}$ & $14.58 \pm 1.60^{\mathrm{b}}$ & $2.76 \pm 0.25^{\mathrm{b}}$ & $0.79 \pm 0.15^{\mathrm{b}}$ & $0.160 \pm 0.126^{\mathrm{a}}$ \\
Nov & $\mathrm{S}$ & $1.12 \pm 0.10^{\mathrm{a}}$ & $37.1 \pm 11.5^{\mathrm{a}}$ & $4.06 \pm 0.55^{\mathrm{a}}$ & $1.22 \pm 0.16^{\mathrm{a}}$ & $0.34 \pm 0.04^{\mathrm{a}}$ & $0.088 \pm 0.028^{\mathrm{a}}$ \\
& $\mathrm{M}$ & $1.94 \pm 0.14^{\mathrm{b}}$ & $54.8 \pm 12.4^{\mathrm{ab}}$ & $6.85 \pm 1.95^{\mathrm{a}}$ & $1.83 \pm 0.26^{\mathrm{b}}$ & $0.48 \pm 0.02^{\mathrm{b}}$ & $0.029 \pm 0.008^{\mathrm{b}}$ \\
& $\mathrm{B}$ & $1.43 \pm 0.12^{\mathrm{c}}$ & $71.8 \pm 7.1^{\mathrm{b}}$ & $10.79 \pm 2.33^{\mathrm{b}}$ & $2.24 \pm 0.38^{\mathrm{b}}$ & $0.35 \pm 0.03^{\mathrm{a}}$ & $0.030 \pm 0.026^{\mathrm{b}}$ \\
& $\mathrm{S}$ & $1.09 \pm 0.13$ & $50.2 \pm 11.4$ & $8.38 \pm 4.55$ & $1.72 \pm 0.68$ & $0.51 \pm 0.18$ & $0.160 \pm 0.065$ \\
& $\mathrm{M}$ & $1.57 \pm 0.39$ & $74.1 \pm 19.6$ & $12.33 \pm 7.02$ & $2.41 \pm 1.01$ & $0.62 \pm 0.23$ & $0.150 \pm 0.131$ \\
& $\mathrm{~B}$ & $1.70 \pm 0.19$ & $112.8 \pm 29.0$ & $12.68 \pm 1.34$ & $2.50 \pm 0.18$ & $0.57 \pm 0.16$ & $0.095 \pm 0.46$ \\
\hline
\end{tabular}


Table 8. Mean $( \pm \mathrm{SD})$ trace element $\left(\mathrm{As}, \mathrm{Cd}, \mathrm{Cr}, \mathrm{Cu}, \mathrm{Zn}, \mathrm{Pb}\right.$ and $\mathrm{Hg}$ ) biodeposition rates $\left(\mu \mathrm{g}\right.$ ind. ${ }^{-1} \mathrm{~d}^{-1}$ ) of Argopecten irradians during September through November in Laizhou Bay. S: small size; M: medium size; B: big size. Different letters in the same month and column indicate significant differences $(p<0.05)$

\begin{tabular}{|ccccccccc|}
\hline Time & Size & As & Cd & Cr & Cu & Pb & Zn & Hg \\
\hline Sep & S & $49.65 \pm 4.34^{\mathrm{a}}$ & $-0.09 \pm 0.04^{\mathrm{a}}$ & $143.90 \pm 17.67^{\mathrm{b}}$ & $53.42 \pm 4.80^{\mathrm{a}}$ & $30.26 \pm 4.41^{\mathrm{a}}$ & $161.15 \pm 16.16^{\mathrm{a}}$ & $0.25 \pm 0.07^{\mathrm{a}}$ \\
& $\mathrm{M}$ & $60.82 \pm 21.82^{\mathrm{a}}$ & $0.14 \pm 0.12^{\mathrm{b}}$ & $101.58 \pm 14.58^{\mathrm{a}}$ & $61.54 \pm 9.91^{\mathrm{a}}$ & $31.48 \pm 8.37^{\mathrm{a}}$ & $219.56 \pm 28.17^{\mathrm{b}}$ & $0.41 \pm 0.08^{\mathrm{a}}$ \\
Oct & $\mathrm{S}$ & $54.96 \pm 14.10^{\mathrm{a}}$ & $-0.06 \pm 0.02^{\mathrm{a}}$ & $160.17 \pm 28.63^{\mathrm{a}}$ & $45.94 \pm 6.02^{\mathrm{a}}$ & $47.73 \pm 11.39^{\mathrm{b}}$ & $157.64 \pm 64.95^{\mathrm{a}}$ & $0.31 \pm 0.04^{\mathrm{a}}$ \\
& $\mathrm{M}$ & $52.10 \pm 9.93^{\mathrm{a}}$ & $-0.05 \pm 0.06^{\mathrm{a}}$ & $163.31 \pm 19.01^{\mathrm{a}}$ & $49.40 \pm 4.30^{\mathrm{a}}$ & $31.79 \pm 2.26^{\mathrm{a}}$ & $187.21 \pm 29.63^{\mathrm{a}}$ & $0.42 \pm 0.07^{\mathrm{a}}$ \\
& $\mathrm{B}$ & $72.74 \pm 5.95^{\mathrm{b}}$ & $0.26 \pm 0.31^{\mathrm{a}}$ & $306.84 \pm 19.73^{\mathrm{b}}$ & $79.32 \pm 9.76^{\mathrm{b}}$ & $52.65 \pm 2.04^{\mathrm{b}}$ & $268.52 \pm 18.95^{\mathrm{b}}$ & $0.44 \pm 0.16^{\mathrm{a}}$ \\
Nov & $\mathrm{S}$ & $42.39 \pm 3.49^{\mathrm{a}}$ & $0.17 \pm 0.15^{\mathrm{a}}$ & $74.80 \pm 5.57^{\mathrm{a}}$ & $34.47 \pm 2.59^{\mathrm{a}}$ & $59.45 \pm 16.72^{\mathrm{a}}$ & $131.61 \pm 14.24^{\mathrm{a}}$ & $0.48 \pm 0.05^{\mathrm{a}}$ \\
& $\mathrm{M}$ & $73.04 \pm 15.98^{\mathrm{b}}$ & $0.05 \pm 0.03^{\mathrm{a}}$ & $115.80 \pm 1.37^{\mathrm{b}}$ & $50.78 \pm 3.72^{\mathrm{b}}$ & $95.36 \pm 33.14^{\mathrm{a}}$ & $201.58 \pm 39.61^{\mathrm{b}}$ & $0.77 \pm 0.13^{\mathrm{b}}$ \\
& $\mathrm{B}$ & $81.56 \pm 12.43^{\mathrm{b}}$ & $0.23 \pm 0.14^{\mathrm{a}}$ & $115.95 \pm 8.97^{\mathrm{b}}$ & $54.78 \pm 6.24^{\mathrm{b}}$ & $80.86 \pm 4.54^{\mathrm{a}}$ & $258.33 \pm 33.77^{\mathrm{b}}$ & $0.87 \pm 0.13^{\mathrm{b}}$ \\
Mean & $\mathrm{S}$ & $46.45 \pm 4.71$ & $0.00 \pm 0.15$ & $119.49 \pm 38.75$ & $42.73 \pm 9.71$ & $45.68 \pm 14.66$ & $144.02 \pm 15.33$ & $0.34 \pm 0.13$ \\
& $\mathrm{M}$ & $61.96 \pm 10.56$ & $0.05 \pm 0.09$ & $126.89 \pm 32.33$ & $53.91 \pm 6.65$ & $52.88 \pm 36.79$ & $202.79 \pm 16.21$ & $0.53 \pm 0.21$ \\
& $\mathrm{~B}$ & $77.15 \pm 6.23$ & $0.24 \pm 0.02$ & $211.39 \pm 134.98$ & $67.05 \pm 17.35$ & $66.75 \pm 19.95$ & $263.42 \pm 7.20$ & $0.65 \pm 0.15$ \\
\hline
\end{tabular}

\section{Clearance rate of bay scallops}

Due to unfavorable weather conditions in September and November, concentrations of TPM could only be determined in the study area during the month of October. The concentrations of TPM, POM and PIM were $17.8 \pm 6.9,3.4 \pm 1.2$ and $14.4 \pm 5.7 \mathrm{mg} \mathrm{l}^{-1}$, respectively. The clearance rate of scallops for the 3 size categories of small, medium and big were $2.28 \pm$ $0.37,3.08 \pm 0.28$ and $4.09 \pm 0.56 \mathrm{l}_{\mathrm{ind}} .^{-1} \mathrm{~h}^{-1}$ (mean \pm $\mathrm{SD})$, respectively, with the largest size being significantly higher than the smallest $(\mathrm{p}<0.01)$. The exponential relationship between clearance rate and tissue $\mathrm{DW}$ was $\mathrm{CR}=2.68 \times W^{0.63}\left(\mathrm{R}^{2}=0.87\right)$.

\section{DISCUSSION}

In this study, we first reported the allometric relationship between biodeposition rates and soft tissue DW of bivalves. The result was in agreement with a previous report (e.g. Haven et al. 1998), that showed biodeposition per soft tissue weight of the mussel Mytilus edulis L. decreased with increasing size (shell length). Our results showed that the biodeposition rates of the bay scallop Argopecten irradians increased allometrically with flesh weight in temperate seasons when water temperatures ranged between 16 and $24^{\circ} \mathrm{C}$. This relationship, however, ceased to exist when water temperatures fell below $10^{\circ} \mathrm{C}$ in the colder months.

This study also demonstrated that the bay scallop biodeposition rates in Laizhou Bay were rather high (1.24 g [g tissue DW $]^{-1} \mathrm{~d}^{-1}$ ) and fall within the upper range reported previously for other filter-feeding bivalves (0.042 to $2.25 \mathrm{~g}$ [g tissue $\mathrm{DW}]^{-1} \mathrm{~d}^{-1}$; Table 9 and references therein). It has also been demonstrated that the bay scallop could enhance the sedimentation of seston, equal to their dry weight in magnitude. Li et al. (2009) estimated the BDR of A. irradians in laboratory raceway tanks to be 0.155 to $0.175 \mathrm{~g}$ $(\mathrm{g} \mathrm{DW})^{-1} \mathrm{~d}^{-1}$. However, the dry weight in their study was the total DW including shells; based on the flesh tissue DW, the BDR was calculated to be 0.62 to $0.70 \mathrm{~g}(\mathrm{~g} \text { tissue } \mathrm{DW})^{-1} \mathrm{~d}^{-1}$, which is lower than the values in our study. The high growth rate $(0.35 \mathrm{~mm}$ $\mathrm{d}^{-1}$ in shell height) and thus high energy demand may contribute to the quick filtration-biodeposition process and sedimentation of TPM.

As is shown in Tables $7 \& 9$, the biodeposition rates of POM and particulate biogenic elements were very high. POM can absorb large quantities of trace elements due to their larger specific surface area and functional groups like carboxyl, ketone and hydroxyl, and cation exchange capacity (Hooda \& Alloway 1998). Thus, the suspension-cultured bay scallops could significantly increase the fluxes of organic matter, biogenic elements and trace elements from the overlying water to the seabed. In Laizhou Bay, A. irradians is cultured at a density of 200 ind. $\mathrm{m}^{-2}$. Based on the mean biodeposition rate of scallops of medium size in October $(54.80 \pm 1.13 \mathrm{~mm}$ shell height), the daily biodeposit production by $A$. irradians amounted to $214 \mathrm{~g} \mathrm{~m}^{-2}$; the daily $\mathrm{C}, \mathrm{N}$ and $\mathrm{P}$ were $1.98,0.36$ and $9.8 \times 10^{-2} \mathrm{~g} \mathrm{~m}^{-2}$, respectively; and the daily trace element ( $\mathrm{As}, \mathrm{Cd}, \mathrm{Cr}, \mathrm{Cu}, \mathrm{Pb}, \mathrm{Zn}$ and $\mathrm{Hg}$ ) biodeposition rates were $10.42,-0.01,32.66,9.88,6.36,37.44$ and $0.08 \mathrm{mg} \mathrm{m}^{-2}$, respectively. For total cultured scallops (ca. $1.07 \times 10^{9}$ ind.) in the bay, the daily biodeposition rate was 1140 metric tonnes (t) dry material, or $10.60 \mathrm{t}$ C, $1.95 \mathrm{t} \mathrm{N}, 0.52 \mathrm{t} \mathrm{TP}, 0.05 \mathrm{t} \mathrm{As},-5.35 \times 10^{-5} \mathrm{t} \mathrm{Cd}, 0.17 \mathrm{t}$ $\mathrm{Cr}, 0.05 \mathrm{t} \mathrm{Cu}, 0.03 \mathrm{t} \mathrm{Pb}, 0.20 \mathrm{t} \mathrm{Zn}$ and $4.49 \times 10^{-4} \mathrm{t} \mathrm{Hg}$. 
Table 9. Comparison of bivalve biodeposition rates. DW: dry weight; TPM: total particulate matter

\begin{tabular}{|c|c|c|c|}
\hline Species & & $\begin{array}{l}\text { deposition rate } \\
\mathrm{mg}[\mathrm{g} \text { tissue } \\
\left.\mathrm{DW}]^{-1} \mathrm{~d}^{-1}\right)\end{array}$ & Reference \\
\hline Mytilus edulis & $\begin{array}{l}\text { TPM } \\
\mathrm{C} \\
\mathrm{N} \\
\mathrm{P}\end{array}$ & $\begin{array}{c}42.4 \\
3.88 \\
0.505 \\
5.49 \times 10^{-2}\end{array}$ & $\begin{array}{l}\text { Kautsky \& Evans } \\
\text { (1987) }\end{array}$ \\
\hline Choromytilus chorus & $\begin{array}{l}\text { TPM } \\
\mathrm{C} \\
\mathrm{N}\end{array}$ & $\begin{array}{l}689 \\
44.1 \\
2.07\end{array}$ & $\begin{array}{l}\text { Jaramillo et al. } \\
\text { (1992) }\end{array}$ \\
\hline Mytilus chilensis & $\begin{array}{l}\text { TPM } \\
\mathrm{C} \\
\mathrm{N}\end{array}$ & $\begin{array}{l}595 \\
35.7 \\
2.38\end{array}$ & $\begin{array}{l}\text { Jaramillo et al. } \\
\text { (1992) }\end{array}$ \\
\hline Modiolus demissus & $\mathrm{N}$ & 1.2 & $\begin{array}{l}\text { Jordan \& Valiela } \\
\text { (1982) }\end{array}$ \\
\hline Modiolus americanus & $\begin{array}{l}\text { TPM } \\
\text { C } \\
\mathrm{N} \\
\mathrm{P}\end{array}$ & $\begin{array}{c}2250 \\
24.8 \\
2.47 \\
8.16 \times 10^{-2}\end{array}$ & $\begin{array}{l}\text { Peterson \& Heck } \\
\text { (1999) }\end{array}$ \\
\hline Chlamys farreri & $\begin{array}{l}\text { TPM } \\
\text { C } \\
\mathrm{N} \\
\mathrm{P}\end{array}$ & $\begin{array}{c}173.1 \\
6.8 \\
0.86 \\
0.22\end{array}$ & $\begin{array}{l}\text { Zhou et al. } \\
\text { (2006a) }\end{array}$ \\
\hline Chlamys farreri & $\begin{array}{l}\text { TPM } \\
\mathrm{C} \\
\mathrm{N} \\
\mathrm{P}\end{array}$ & $\begin{array}{c}122.3 \\
6.3 \\
0.80 \\
0.17\end{array}$ & $\begin{array}{l}\text { Zhou et al. } \\
\text { (2006b) }\end{array}$ \\
\hline Argopecten irradians & TPM & $617-697$ & Li et al. (2009) \\
\hline Patinopecten yessoensis & TPM & 686 & Yuan et al. (2010) \\
\hline Mytilus edulis & $\begin{array}{l}\mathrm{C} \\
\mathrm{N} \\
\mathrm{P}\end{array}$ & $\begin{array}{l}2.69 \\
0.31 \\
0.02\end{array}$ & Jansen et al. (2012) \\
\hline Argopecten irradians & $\begin{array}{l}\text { TPM } \\
\mathrm{C} \\
\mathrm{N} \\
\mathrm{P}\end{array}$ & $\begin{array}{l}1244 \\
9.49 \\
1.95 \\
0.58\end{array}$ & Present study \\
\hline
\end{tabular}

Thus, biodeposition loadings from subtidal bay scallop culture can be significant. Furthermore, the harvest of scallops can potentially remove $966 \mathrm{t} \mathrm{C}, 236 \mathrm{t} \mathrm{N}$, and $20.89 \mathrm{t} \mathrm{P}$ in their soft tissue and $2046 \mathrm{t} \mathrm{C}, 16.6 \mathrm{t} \mathrm{N}$, $3.33 \mathrm{t}$ OP and $5.33 \mathrm{t} \mathrm{TP}$ in their shells (Table 10). The organic concentration of surface sediments in Laizhou

Table 10. Annual nutrient removals (in tonnes) from the Laizhou Bay ecosystem through the harvest of bay scallops in November. C: carbon; N: nitrogen; TP: total phosphorus; OP: organic phosphorus; (-) not measured

\begin{tabular}{|lcccc|}
\hline Nutrient removal & C & N & OP & TP \\
\hline Soft tissue harvest & 966 & 236.2 & - & 20.89 \\
Shell harvest & 2046 & 16.6 & 3.33 & 5.33 \\
\hline
\end{tabular}

Bay is relatively low, with a TOC of approx. $0.30 \%$ and $\mathrm{TN}$ of $0.03 \%$ (Table 11 ). The large quantities of biodeposits produced by the densely cultured bay scallops may compensate for the deficiency of organic matter in seabed and increase the secondary production rate of the benthos.

Enrichment of OM, OC and TN in sediments produced by biodeposits of suspension feeders has been found in various coastal waters (Vinther \& Holmer 2008, Yuan et al. 2010, Rampazzo et al. 2013). This study also found that the OM concentration in sediments from traps containing bay scallops was significantly higher than those in reference traps, which suggested that the bay scallops may have a preference for the organic-enriched matter in the water column. Evidence from a previous laboratory study conducted by Heinonen et al. (2007) showed that the feeding activities of suspension feeders (i.e. the blue mussel $M$. edulis and the bay scallop A. irradians) could significantly enhance transparent exopolymer particle (TEP) concentrations in ambient waters, which could lead to enhanced flocculation of $\mathrm{OM}$ and $\mathrm{C}$ deposition in near-shore waters. The TEP production by densely cultured scallops may be more intense and contribute to the sedimentation of $\mathrm{OM}$ and the enrichment of sediment. The OM concentration of faeces produced by bay scallops feeding on a diet of phytoplankton (Chrysophyceae) and kelp is 33.31 and $24.14 \%$ (Mao et al. 1997), well above that of the natural sediment $(<5 \%$; Fig. 3$)$.

The allometric relationship between clearance rate and tissue DW $\left(\mathrm{CR}=2.68 \times W^{0.63}\right)$ was modeled. The value of $b$ in the equation is 0.63 , similar to the mean of from 21 bivalves (0.62), as reviewed by Cranford et al. (2011). In the present study, the clearance rate of standard tissue DW $(1 \mathrm{~g})$ was $2.68 \mathrm{l}$ ind.$^{-1} \mathrm{~h}^{-1}$. This value is higher than laboratory determined values (shell height $50-51 \mathrm{~mm}, 0.23-0.89 \mathrm{l} \mathrm{g}^{-1} \mathrm{~h}^{-1}$, Li et al. 2009; shell height 22-24 mm, 0.48-1.97 $\mathrm{l} \mathrm{g}^{-1} \mathrm{~h}^{-1}$, Wang et al. 2000). It has been suggested that these differences may be attributed to a disparity in scallop size, temperature, seston quantity and quality and also possibly research methodologies. 
Table 11. Organic concentrations of surface sediments (mean in parentheses if available) in Laizhou Bay. TOC: total organic carbon; TN: total nitrogen; OM: organic matter

\begin{tabular}{|lll|}
\hline & Range (mean) & Reference \\
\hline TOC & $0.10-0.58(0.32)$ & Hu et al. (2011) \\
& $0.07-0.54(0.25)$ & Wu et al. (2014) \\
& $0.12-1.5$ & Gao et al. (2013) \\
& $0.05-0.60(0.24)$ & Zhang et al. (2014) \\
TN & $0.01-0.06(0.03)$ & Zhang et al. (2014) \\
OM & $0.2-1.3$ & Liu et al. (2004) \\
& $0.11-0.98(0.37)$ & Zhou et al. (2010) \\
& 0.76 & Zhou et al. (2012) \\
& 0.59 & Zhou et al. (2012) \\
& & \\
\end{tabular}

\section{CONCLUSIONS}

This study indicated that suspended bay scallop mariculture in Laizhou Bay may have a significant impact on the ambient coastal ecosystems through the filtering-biodeposition process. Large amounts of nitrogen and phosphorus are removed from the aquatic system during harvesting. The intensely cultured scallops in the bay may function as biofilters or recyclers by mitigating the eutrophication and trace element pollution pressure on the coastal ecosystem by controlling seston and phytoplankton levels via filtering-biodeposition processing and removing excessive nutrients from the ecosystem, while simultaneously generating valuable products. In coastal waters and estuaries subject to anthropogenic nutrient and trace element inputs, suspended bivalve aquaculture could be environmentally advantageous via intense filtering and biodeposition, as well as by potentially mitigating eutrophication and trace element pressures.

Acknowledgements. We thank Guozhen Feng for his help in the field experiment. This research was supported by the National Natural Science Foundation of China (No. 41176140/30972268), the NSFC-Shandong Joint Fund for Marine Science Research Centers (No. U1606404), the key Research and Development Project of Shandong Province (2017GHY15111), the Key Projects in the National Science \& Technology Pillar Program during the 12th Five-year Plan Period (2011BAD13B06), the National Science \& Technology Basic Work Program (2015FY110600), and the Taishan Scholars Program (Distinguished Taishan Scholars).

\section{LITERATURE CITED}

Andersen JH, Carstensen J, Conley DJ, Dromph K and others (2017) Long-term temporal and spatial trends in eutrophication status of the Baltic Sea. Biol Rev Camb Philos Soc 92:135-149
Anderson DM, Burkholder JM, Cochlan WP, Glibert PM and others (2008) Harmful algal blooms and eutrophication: examining linkages from selected coastal regions of the United States. Harmful Algae 8:39-53

* Bayne BL (2009) Carbon and nitrogen relationships in the feeding and growth of the pacific oyster, Crassostrea gigas (Thunberg). J Exp Mar Biol Ecol 374:19-30

Bayne BL, Newell RC (1983) Physiological energetics of marine molluscs. In: Saleuddin ASM, Wilbur KM (eds) The Mollusca, Vol. 4: Physiology, Part I. Academic Press, New York, NY, p 407-515

* Beseres Pollack J, Yoskowitz D, Kim HC, Montagna PA (2013) Role and value of nitrogen regulation provided by oysters (Crassostrea virginica) in the Mission-Aransas Estuary, Texas, USA. PLOS ONE 8:e65314

Callier MD, McKindsey CW, Desrosiers G (2007) Multi-scale spatial variations in benthic sediment geochemistry and macrofaunal communities under a suspended mussel culture. Mar Ecol Prog Ser 348:103-115

Chen BJ, Chen JF, Cui Y, Li QF, Yuan YX (2001) The ecological characteristics of phytoplankton in the Eastern marine culture area of Laizhou Bay. Mar Fish Res 22:64-70 (in Chinese with English Abstract)

* Cranford PJ, Hill PS (1999) Seasonal variation in food utilization by the suspension-feeding bivalve molluscs Mytilus edulis and Placopecten magellanicus. Mar Ecol Prog Ser 190:223-239

Cranford PJ, Ward JE, Shumway SE (2011) Bivalve filter feeding: variability and limits of the aquaculture biofilter. In: Shumway SE (ed) Shellfish aquaculture and the environment. Wiley-Blackwell, Oxford, p 81-124

* Crawford CM, Macleod CK, Mitchell IM (2003) Effects of shellfish farming on the benthic environment. Aquaculture 224:117-140

*Deegan LA, Johnson DS, Warren RS, Peterson BJ, Fleeger JW, Fagherazzi S, Wollheim WM (2012) Coastal eutrophication as a driver of salt marsh loss. Nature 490:388-392

* Doney SC (2010) The growing human footprint on coastal and open-ocean biogeochemistry. Science 328:1512-1516

* Filgueira R, Guyondet T, Reid GK, Grant J, Cranford PJ (2017) Vertical particle fluxes dominate integrated multitrophic aquaculture (IMTA) sites: implications for shellfish-finfish synergy. Aquacult Environ Interact 9:127-143

Gao XL, Li P, Chen CTA (2013) Assessment of sediment quality in two important areas of mariculture in the Bohai sea and the northern Yellow Sea based on acid-volatile sulfide and simultaneously extracted metal results. Mar Pollut Bull 72:281-288

Gao XL, Zhou FX, Chen CTA (2014) Pollution status of the Bohai Sea: an overview of the environmental quality assessment related trace metals. Environ Int 62:12-30

* Grant J, Hatcher A, Scott DB, Pocklington P, Schafer C, Winters G (1995) A multidisciplinary approach to evaluating impacts of shellfish aquaculture on benthic communities. Estuaries 18:124-144

* Grizzle RE, Ward KM, Peter CR, Cantwell M, Katz D, Sullivan J (2017) Growth, morphometrics and nutrient content of farmed eastern oysters, Crassostrea virginica (Gmelin), in New Hampshire, USA. Aquacult Res 48: 1525-1537

Halpern BS, Walbridge S, Selkoe KA, Kappel CV and others (2008) A global map of human impact on marine ecosystems. Science 319:948-952

Haven DS, Morales-Alamo R (1972) Biodeposition as a factor in sedimentation of five suspended solids in estuaries. 
Mem Geol Soc Am 133:121-130

Haven DS, Morales-Alamo R, Kotta J, Orav H (1998) Biodeposition rates of blue mussel, Mytilus edulis L., in the laboratory and field conditions in relation to water temperature, phytoplankton density and mussel size. ICES Symposium on Marine Benthos Dynamics, Environmental and Fisheries Impacts, 5-7 Oct 1998, Heraklion. ICES, Copenhagen

KHayakawa Y, Kobayashi M, Izawa M (2001) Sedimentation flux from mariculture of oyster (Crassostrea gigas) in Ofunato Estuary, Japan. ICES J Mar Sci 58:435-444

Heinonen K, Ward J, Holohan B (2007) Production of transparent exopolymer particles (TEP) by benthic suspension feeders in coastal systems. J Exp Mar Biol Ecol 341: 184-195

Hoellein TJ, Zarnoch CB, Grizzle RE (2015) Eastern oyster (Crassostrea virginica) filtration, biodeposition, and sediment nitrogen cycling at two oyster reefs with contrasting water quality in Great Bay Estuary (New Hampshire, USA). Biogeochemistry 122:113-129

Hooda P, Alloway B (1998) Cadmium and lead sorption behaviour of selected English and Indian soils. Geoderma 84:121-134

Hu NJ, Shi XF, Liu JH, Huang P, Yang G, Liu YG (2011) Distributions and impacts of heavy metals in the surface sediments of the Laizhou Bay. Mar Fish Res 29:63-72 (in Chinese with English Abstract)

Huang LM, Huang XP, Song XY, Tan YH, Wang HK (2003) Frequent occurrence area of red tide and its ecological characteristics in Chinese coastal waters. Ecol Sci 22: 252-256 (in Chinese with English Abstract)

Iglesias J, Urrutia M, Navarro E, Ibarrola I (1998) Measuring feeding and absorption in suspension-feeding bivalves: an appraisal of the biodeposition method. J Exp Mar Biol Ecol 219:71-86

Jansen HM, Strand O, Verdegem M, Smaal A (2012) Accumulation, release and turnover of nutrients (C-N-P-Si) by the blue mussel Mytilus edulis under oligotrophic conditions. J Exp Mar Biol Ecol 416-417:185-195

* Jaramillo E, Bertrán C, Bravo A (1992) Mussel biodeposition in an estuary in southern Chile. Mar Ecol Prog Ser 82: 85-94

Jordan TE,Valiela I (1982) A nitrogen budget of the ribbed mussel, Geukensia demissa, and its significance in nitrogen flow in a New England salt marsh. Limnol Oceanogr 27:75-90

Kautsky N, Evans S (1987) Role of biodeposition by Mytilus edulis in the circulation of matter and nutrients in a Baltic coastal ecosystem. Mar Ecol Prog Ser 38:201-212

* Li Y, Veilleux DJ, Wikfors GH (2009) Particle removal by northern bay scallops Argopecten irradians irradians in a semi-natural setting: application of a flow-cytometric technique. Aquaculture 296:237-245

KLi R, Liu S, Zhang J, Jiang Z, Fang J (2016) Sources and export of nutrients associated with integrated multitrophic aquaculture in Sanggou Bay, China. Aquacult Environ Interact 8:285-309

Liang XM, Fang JG, Cui Y, Tang QS (2001) Seston dynamics in bay scallop (Argopecten irradians Lamarck) mariculture area of Laizhou Bay. Oceanol Limnol Sin 32:635-640 (in Chinese with English Abstract)

Liu H, Fang J, Zhu J, Dong S and others (2004) Study on limiting nutrients and phytoplankton at long-line-culture areas in Laizhou Bay and Sanggou Bay, northeastern China. Aquat Conserv 14:551-574
Mao XH, Hao YW, Yang XL (1997) The carbon metabolism and energy metabolism of Argopecten irradians and Chlamys farreri. Acta Oceanol Sin 19:132-137 (in Chinese)

* Micheli F (1999) Eutrophication, fisheries, and consumerresource dynamics in marine pelagic ecosystems. Science 285:1396-1398

NCSB (North China Sea Branch of State Oceanic Administration) (2011) Report on the state of the marine environment in North China Sea, 2011. State Oceanic Administration, Beijing

Newell RI (2004) Ecosystem influences of natural and cultivated populations of suspension-feeding bivalve molluscs: a review. J Shellfish Res 23:51-62

Nielsen P, Cranford PJ, Maar M, Petersen JK (2016) Magnitude, spatial scale and optimization of ecosystem services from a nutrient extraction mussel farm in the eutrophic Skive Fjord, Denmark. Aquacult Environ Interact 8:311-329

NMEB (National Marine Environment Bulletin) (2009) National Marine Environment Bulletin of 2009.

*Pan K, Wang WX (2012) Trace metal contamination in estuarine and coastal environments in China. Sci Total Environ 421-422:3-16

* Petersen JK, Hasler B, Timmermann K, Nielsen P, Tørring DB, Larsen MM, Holmer M (2014) Mussels as a tool for mitigation of nutrients in the marine environment. Mar Pollut Bull 82:137-143

* Peterson BJ, Heck KL Jr (1999) The potential for suspension feeding bivalves to increase seagrass productivity. J Exp Mar Biol Ecol 240:37-52

Qu KM, Cui Y, Xin FY, Chen MS, Song YL, Yuan YX (2002) The plane distributions and seasonal variations of nutrients in the east of Laizhou Bay. Mar Fish Res 23:37-46 (in Chinese with English Abstract)

* Rampazzo F, Berto D, Giani M, Brigolin D and others (2013) Impact of mussel farming on sedimentary geochemical properties of a Northern Adriatic area influenced by freshwater inflows. Estuar Coast Shelf Sci 129:49-58

$*$ R Development Core Team (2016) R: a language and environment for statistical computing. R Foundation for Statistical Computing, Vienna. www.r-project.org

Shan ZX, Zheng ZH, Xing HY, Liu XJ, Liu XB, Liu YH (2000) Study of eutrophication in Laizhou Bay of Bohai. Trans Oceanol Limnol 2:41-46 (in Chinese with English Abstract)

* Smith VH, Tilman GD, Nekola JC (1999) Eutrophication: impacts of excess nutrient inputs on freshwater, marine, and terrestrial ecosystems. Environ Pollut 100:179-196

* Solórzano L, Sharp JH (1980) Determination of total dissolved phosphorus and particulate phosphorus in natural waters. Limnol Oceanogr 25:754-758

Stadmark J, Conley DJ (2011) Mussel farming as a nutrient reduction measure in the Baltic Sea: consideration of nutrient biogeochemical cycles. Mar Pollut Bull 62: 1385-1388

* Testa JM, Brady DC, Cornwell JC, Owens MS and others (2015) Modeling the impact of floating oyster (Crassostrea virginica) aquaculture on sediment-water nutrient and oxygen fluxes. Aquacult Environ Interact 7: 205-222

* Vinther HF, Holmer M (2008) Experimental test of biodeposition and ammonium excretion from blue mussels (Mytilus edulis) on eelgrass (Zostera marina) performance. J Exp Mar Biol Ecol 364:72-79

Wang RC, Wang ZP (2008) Science of marine shellfish culture. China Ocean University Press, Qingdao (in Chinese) 
Wang F, Dong SL, Zhang S, Wang RC (2000) Experimental studies on feeding selectivity and the filter-feeding rate of Argopecten irradians and Crassostrea gigas. Oceanol Limnol Sin 31:139-144 (in Chinese with English Abstract)

Wang F, Xu SC, Zhou Y, Wang PM, Zhang XM (2017) Trace element exposure of whooper swans (Cygnus cygnus) wintering in a marine lagoon (Swan Lake), northern China. Mar Pollut Bull 119:60-67

Wang H, Dai MH, Liu JW, Kao SJ and others (2016) Eutrophication-driven hypoxia in the East China Sea off the Changjiang Estuary. Environ Sci Technol 50:2255-2263

Waycott M, Duarte CM, Carruthers TJB, Orth RJ and others (2009) Accelerating loss of seagrasses across the globe threatens coastal ecosystems. Proc Natl Acad Sci USA 106:12377-12381

Wu B, Song J, Li X (2014) Evaluation of potential relationships between benthic community structure and toxic metals in Laizhou Bay. Mar Pollut Bull 87:247-256

Yu ZH, Zhou Y, Qi ZH, Luo P, Hu CQ (2017) Temporal dynamics in clearance rate of the Portuguese oyster Crassostrea angulata cultivated in Dapeng Cove, southern China. Aquaculture 479:824-828

Y Yuan X, Zhang M, Liang Y, Liu D, Guan D (2010) Selfpollutant loading from a suspension aquaculture system of Japanese scallop (Patinopecten yessoensis) in the Changhai Sea area, northern Yellow Sea of China. Aquaculture 304:79-87

Zhang FS (1986) The development of bay scallop (Argopecten irradians) mariculture in China. Mark Sci 4:1-4 (in Chinese)

Zhang Y, Lv Z, Guan B, Liu Y and others (2013) Status of macrobenthic community and its relationships to trace metals and natural sediment characteristics. CLEANSoil Air Water 41:1027-1034

Zhang JF, Gao XL, Zhuang W, Li PM, Zhou FX (2014) Analysis of long-term changes in fisheries resources and

Editorial responsibility: Gianluca Sará,

Palermo, Italy environment in the Laizhou Bay. Trans Oceanol Limnol 3:82-90 (in Chinese with English Abstract)

Zhao J, Chen J (2001) Research on aquacultural hydroenvironment of Eastern Laizhou Bay. Mar Fish Res 22: 62-67 (in Chinese with English Abstract)

Zhou Y, Zhang F, Yang H, Zhang S, Ma X (2003) Comparison of effectiveness of different ashing auxiliaries for determination of phosphorus in natural waters, aquatic organisms and sediments by ignition method. Water Res 37:3875-3882

Zhou Y, Yang H, Zhang T, Liu S and others (2006a) Influence of filtering and biodeposition by the cultured scallop Chlamys farreri on benthic-pelagic coupling in a eutrophic bay in China. Mar Ecol Prog Ser 317:127-141

* Zhou Y, Yang H, Zhang T, Qing P, Xu X, Zhang F (2006b) Density-dependent effects on seston dynamics and rates of filtering and biodeposition of the suspension-cultured scallop Chlamys farreri in a eutrophic bay (northern China): an experimental study in semi-in situ flowthrough systems. J Mar Syst 59:143-158

Zhou H, Hua E, Zhang Z (2010) Community structure of macrobenthos in Laizhou Bay and adjacent waters. Period Ocean Univ China 40:80-87 (in Chinese with English Abstract)

Khou H, Zhang Z, Liu X, Hua E (2012) Decadal change in sublittoral macrofaunal biodiversity in the Bohai Sea, China. Mar Pollut Bull 64:2364-2373

* Zhuang W, Gao X (2013) Acid-volatile sulfide and simultaneously extracted metals in surface sediments of the southwestern coastal Lizhou Bay, Bohai Sea: concentrations, spatial distributions and the indication of heavy metal pollution status. Mar Pollut Bull 76:128-138

Zúñiga D, Castro CG, Aguiar E, Labarta U and others (2014) Biodeposit contribution to natural sedimentation in a suspended Mytilus galloprovincialis Lmk mussel farm in a Galician Ría (NW Iberian Peninsula). Aquaculture 432: 311-320

Submitted: August 23, 2017; Accepted: January 17, 2018 Proofs received from author(s): February 28, 2018 